\title{
LANCASHIRE SECTION: Meeting at Manchester, 10th October, 1919: Mr. W. Greenwood in the Chair: INDUSTRIAL ADMINISTRATION
}

\section{A. F. Stanley Kent D.Sc.}

To cite this article: A. F. Stanley Kent D.Sc. (1919) LANCASHIRE SECTION: Meeting at Manchester, 10th October, 1919: Mr. W. Greenwood in the Chair: INDUSTRIAL ADMINISTRATION, Journal of the Textile Institute Proceedings and Abstracts, 10:11, 314-317, DOI: $10.1080 / 00405001908630955$

To link to this article: http://dx.doi.org/10.1080/00405001908630955

曲 Published online: 25 Nov 2008.

Submit your article to this journal $₫$

Ш Article views: 3

Q View related articles ¿ 
the use of New Zealand crossbreds which cannot be obtained from the wools of either Great Britain, South America, or even the United States. In these wools there are properties which, if rightly used in the hands of home spinners and manufacturers, will always mean the supremacy of their industry.

The great frozen mutton trade has been a very important contributing factor to the success of the woollen trade of both Scotland and Yorkshire, and I think that the experience which manufacturers have obtained during the past five years of war has revealed to many a firm that there is in the sliped crossbred wools of New Zealand manufacturing properties of which they had no conception. I know that is so in the West Riding. Firms I could name, who have always looked askance at sliped wools, were compelled during the war to use them in the production of khaki fabrics, and I venture to say to say that they will continue to use these wools to the end of the chapter. Why? Because the bulk of them are the right length of staple for the woollen cards. On the whole, they are well classed, the wools can be used straight from the bales, and the resultant fabrics are always sound. It is indeed a remarkable fact that one seldom comes across tenderness of staple in the sliped crossbred wools of New Zealand. Notwithstanding that a certain proportion of lime has been used in painting the skins, in, order to remove the wool, actual results show that the wool has suffered practically nothing by the process. Such properties as colour, length of staple, soundness, and softness of handle are all features that stand out prominently in connection with the wools of New Zealand, and when carefully sorted into their respective qualities, a man can obtain whatever he wants from 36's up to 58's and be well satisfied with the final results in the yarn and the piece.

There is just one feature of outstanding prominence and interest to Scottish woollen manufacturers. I have not time to-night to stop to emphasise the results in the fleece by the use of the Lincoln, Leicester, Romney Marsh, and Down sires upon the crossbred ewes of New Zealand, but to a careful observer they are very significant. The bulk of the crossbreds show a big, compact staple, the fibres being more or less flat. An old Yorkshire cloth maker once said " they lie low" in the piece. But that is not so in all cases, and a man wanting a "blobby" yarn-that is, a yarn of a very lofty character-can find it-at least a portion-in the wools of New Zealand. The practice is a growing one among New Zealand pastoralists to mate a crossbred ewe with wool of 46's quality with a Down sire, the resultant cross producing a full handling, blobby fibre which, to my mind, is ideal where that class of yarn is wanted.

A word is necessary in regard to the wools of South Africa. I am certain that British manufacturers have not yet fully discovered the properties to be found in South African wools. I foretell a larger consumption of good combing Cape wools by British manufacturers. The large importation of merino stud sheep from Australia has certainly been a move in the right direction. Many flocks have benefited so materially. during the past 10 years that the character of the South African merinos has greatly improved. In my opinion, the merinos of South Africa will never suffer on account of quality, and with a deeper staple, one showing more length and character, they are bound to be appreciated by the spinners and manufacturers of this district.

I think that Colonial wools offer such a range of qualities and characteristics as to meet practically all the demands of the woollen, worsted, and hosierv trades of Great Britain, and, in conclusion, I would say : Study Colonial wools, look at them from every standpoint, experiment with them, and I believe that even Scottish manufacturers may find in them capabilities of advantage.

At the conclusion of the lecture, many interesting lantern slides were shown on the screen, whilst a collection of specimens of wool was open to inspection.

After a number of questions had been asked and answered, a hearty vote of thanks, on the motion of the Chairman, was accorded to Mr. Hollings.

\section{LANCASHIRE SECTION}

Meeting at Manchester, 10th October, 1919.

Mr. W. Greenwood in the Chair.

\section{INDUSTRIAL ADMINISTRATION}

\section{By A. F. Stunley Kent, D.Sc.}

Asked to speak on this subject, the opportunity occurs because I am responsible for the direction of the Department of Industrial Administration in the Manchester Municipal College of Technology. It must be recognised, however, that the position of this department is rather that of a pioneer that will contribute its quota, act as a centre of information, research, and teaching, and assist in the ultimate elaboration of a Science of Industrial Administration than that of an institution designed to deal with a subject already brought to perfection, or even fully outlined, whilst its Director is rather to be regarded as one who early recognised the importance of some of the questions involved, and initiated research and teaching thereon, where little existed previously, than as one who makes any claim to the position of an expert in the whole subject of administration.

It was almost by accident that the first department of industrial administration to come into existence had its origin in Manchester. Already in Bristol work had been in progress for several years, and the need for co-ordination of the different sections of the scheme had led to a committee being formed to deal with it, with the Lord Mayor at its head, and with Bristol's most energetic industrial leaders as its members. But things move quickly in the north, and about this time a number of large firms engaged in the principal industries of the Manchester district came together, discussed the necessity of action, and by their generosity enabled the Municipal College of Technology to establish such a department.

During the past year work has been commenced. A director has been appointed to organise the depart. ment, to conduct research in the subject, to lecture to the students and the public, and to assist industrial concerns in the solution of their administrative problems. As assistants, he has a number of experts 
in various branches of administration, who devote their whole time to the work of the department, whilst outside help is continually called on in branches not thus provided for.

It was felt from the first that the department must be kept close in touch with practice, and, to secure this, its students are allowed to study various points of administration in neighbouring works where these have received particular attention, whilst managers, directors, scientific experts, and others with special qualifications are asked to deliver occasional public lectures.

In the near future, industrial administration will be a problem of greater complexity than ever, owing especially to the growing aspirations of labour to an increasing share in management. The change that is sure to come will be more or less orderly in the manner of its coming according as the attitude of employers, managers, and workers is more or less enlightened.

Management should be regarded as a profession calling for specific training and instruction. In future no manager should be considered as qualified in the fullest sense unless he has studied the science of administration as something distinct from the technique of his particular industry. In the past managers have been appointed because they happened to be good engineers or manufacturers. But technique and administration are separate and distinct functions. The best technical man is not necessarily a competent administrator. As a rule, much study is given to technical qualifications; it is not unreasonable to propose that at least some attention should be devoted to the science of administration.

At the present time no complete science of administration can be said to exist. Such a science can only be developed gradually by the joint efforts of the director and his staff, paid lecturers and helpers from outside, and the fullest co-operation of business men actually engaged in commerce and industry.

One of the chief functions of the new department should be the collection and co-ordination of existing knowledge and making it available for general use. When one scrutinises all that has been done in the science of administration, however, it becomes evident at once that much remains undone. Indeed, in some directions scarcely a beginning has been made, and methods most primitive are still employed. Thus, it comes about that another chief function of the department must be research.

We hear a great deal of the need for greater output and of the unwillingness of the men to co-operate in securing it. What is the cause of this tendency? Perhaps we shall not be far wrong if we recognise as one important cause the large amount of ignorance that we-the so-called educated classes-have allowed to exist amongst the workers. Much has been done for education in the past few years, but we have failed altogether to recognise the type of education necessary to train up a generation of workers equipped with knowledge and understanding to make proper use of the enormous powers that circumstances have now called upon them to wield. That the restriction of output is regarded as providing work for more numerous workers, and that machinery is loathed as the workers' bitterest enemy, are commonplaces.
Probably, many of use realise that much lies beneath. High wages are not the ultimate goal of the workers' leaders, though they appeal powerfully to the worker, and therefore form an excellent rallying cry certain to attract a following. The object of the leaders is rather to secure fundamental changes that shall give them a share of control of industry. Be this as it may, however, it appears that wages, not always determined by reason, but by ill-considered use of power, may yet be vastly higher; large sums must be spent on improved conditions under which labour is to be per. formed, and hours of working will be shorter. This is the conclusion forced upon an unprejudiced observer, and it is one to emphasise most strongly the urgent need of improved production. On this particular question America has scarcely been at all affected by any complaint that limitation of output provides work for extra men, or that the extension of machinery reduces the demand for labour. It has been stated that-

"Owing to the general diffusion of intelligence, it was recognised early in the history of American in. dustry that increase of products, however brought about, raises the standard of living. Increase of products brings about increase of consumption, and the more machinery is employed the greater the increase of product. The general intelligent belief in these truths has been brought about in the U.S.A. very largely by the system which prevails of experts moving about from State to State and from city to city, and lecturing on economic subjects."

Thus, we are brought at once against the fact that in the U.S.A. there exists, amongst the operatives, sufficient appreciation of economic truths to save them from the mistakes of our own industrial workers, and the need of revising our education of the masses, and of providing a training that shall fit them to exercise the functions of citizenship is emphasised. America does not tell us how to get out of our difficulty, but she shows how she herself has avoided it. And the answer to the question-" What is to be done?"-is "Provide a suitable education." To undertake anything of the kind just now may seem hopeless, but it is proposed that the attempt shall be initiated through the machinery of our new department-by public lectures, distribution of printed reports of the lectures, a full-time course of study for those who can attend in the daytime, evening classes, facilities for consulta. tion of literature on industrial administration, and the arrangement of evening lectures in various localities. Research, however, is of the first importance, not only in the factory, but in the laboratory, where new methods are devised and tested and ceaseless work is necessary. It is hardly possible to conceive of a more hopeful investment at the present time than an ample provision for research.

To return to the matter of the need of greater output. We are perpetually told that the only hope for industry lies in greater productivity. I suppose we may take the statement to mean that with increased output prosperity may be looked for, even under present altered conditions, and, if this is so, our first effort should be to see upon what increased productivity depends. In the past, probably, hardly any industrial enterprise was worked up to the limits of its productiveness, since no special reason for this existed. Desire for higher dividends and the gradual rise in 
wages has, however, led to the tightening up of administration and to the elimination of the more obvious kinds of waste. The process has not always gone very far, partly because the need has only lately become apparent, and partly because, in some directions, the necessiry knowledge is only now coming into our possession. If, then, a wasteful administration is still the rule, it may be that here we have our first opportunity of effecting an improvenent. In the first place, there is in many industrial concerns a waste of time that is colossal. Time may be regarded as wasted when it fails to produce its own useful tale of work. and fails also to assist in due production of other periods. We have to recognise wasted time and then determine how it must be dealt with. This involves a careful serutiny of the whole of the working day and even of the working week. By careful work and experiments, carried on over a sufficient time to eliminate accidental fluctuations, and dealing with a sufficiently large number of individuals to secure a satisfactory average, the "time relations" of the week could be perfectly adjusted in the sense that each period would be so co-ordinated with its neighbours as to assist. rather than to linder, in obtaining the result aimed at, namely, a perfectly-timed working period. in which production could be maintained at a pre-determined level, with the least possible fatigue to the worker. in the most advantageous time and at the smallest cost withont the most careful ramination of conditions. It is quite hopeless to attempt to apply the results obtained in one factory to the problems of another, for conditions affect the result profoundly. and altered conditions may lead to results that are altogether misleating. Should it be found impossible to attiin a co-ordination as completo as that described, with its accompanying enormous saving of time, it may be easy to apply a partial remedy and eliminate wasted time where it is most in evidence-voluntarily and involuntarily wasted time.

(At this stage the lecturer gave details of a number of experiments and investigations it industrial establishments and exhibited a number of lantern slides indicative of the effect of rearrangement of working hours, ete. Subjoined is a record provided from a mill -doubliug department-in the Manchester area.)

\section{WORKERS ABSENT THROUGH SICKNLSS AND OTHER CAUSES.}

OLD THE. -13 weeks (a) $551 \frac{1}{2}$ hours weekly, -120 workpeople, principally females.

\begin{tabular}{|c|c|c|c|c|c|c|c|c|}
\hline \multirow{2}{*}{ Average } & \multicolumn{2}{|c|}{60 persons } & \multicolumn{4}{|c|}{ 2t hours each week } & \multicolumn{2}{|c|}{$=150$ hours. } \\
\hline & 10 & , & 10 & , & ., & ., & $=100$ & $"$ \\
\hline " & 10 & " & $55 \frac{1}{1}$ & " & .. & .. & $=655$ & ", \\
\hline & & & & alal & liou & lost. & & \\
\hline
\end{tabular}

Now TME.-13 weeks $\ddot{a} 48$ hours weekly.-420 workpeople, principally females.

\begin{tabular}{|c|c|c|c|c|c|c|c|}
\hline & person & $4+1$ & Durs & eacl. & week & & 1111 \\
\hline \multirow{2}{*}{$\begin{array}{c}\text { Average } \\
. . \\
. .\end{array}$} & ,. & 8 & , & ., & ," & $=17+6$ & $"$ \\
\hline & * & & , & $"$ & " & 110 & \\
\hline & & & To & al ho & ars log & 371 & \\
\hline
\end{tabular}

Any effectual steps towards the diminution of noise would save much wasted energy, especially if in regard to the neighbourhood of our sleeping workers. Even the children of the working classes enjoy far too little of quiet sleep. In the future we shall regard to-day's indifference to uncontrolled noise during the hours that should be devoted to sleep as an altogether unaccountable madness, responsible for much of our present inefficiency.

(After alluding to Motion Study and Waste of Energy, the lecturer proceeded to deal with the subject of Vocational Selection.)

There are scientific ways of selecting cattle, horses, and pigs. Materials, tools, and equipment are scrutinised most minutely, and yet when it comes to the choice of his own life work, the guidance of his children in their vocations, or the seleotion of employees or co-workers, the average man decides the entire matter by almost any other consideration than scientifically determined fitness. Is it not time that man should learn about himself and others, and especially about those things which are vital to even a moderate enjoyment of the good things of life? This study has not so far been given a trial of any great magnitude in this country. We must study the best methods in practice elsewhere, and we must undertake research in order to improve on those methods. We must also train our students entering for a course of instruction in industrial administration in order that they may take a practical interest in developing this movement in any industry with which they may become associated. The best man available is the light man for the post, and, if several candidates were sent to the department for seleotion, the prospects of success would bo increased.

Agrial, there is the question of waste of materialwith which I cammot deal-waste of happiness, and waste of life. Probably, sickness leads to the greatest waste of happiness and leads up to the waste of life. How cau sickness be diminished? No doubt the advance of medicine and hygiene will yield great results. It is our business to make certain that these results are actually applied in the works and in the lome. Until this is done they are useless, so far as industry is concerned. We must fight agaiust tubercle, venereal disease, and excessive drinking, and we must take care to regulate hours of work, rest periods, and all conditions in the factory and in the home.

On the economic side, our department makes the attempt to solve the dilemma of labour relations. special attention being given to profit sharing, wage systems, employment management, welfare work. co-operation, works committees, scientific management. and general organisation. I have indicated some of the activities of a young department which is feeling its way and is still hampered by lack of staff, accommodation, and resources. Soon we hope to do more. and especially to undertake more extensive research work. That there is urgent need of it is beyond all question.

\section{Discussion.}

Asked for information as to tests in cases where output is regarded as fixed by the speed of machinery. the Lecturer stated that even in spinning it was found that there were productive and unproductive periods of the day.

Mr. J. II. Lester (Manchester) said that in a case where two factories had been under consideration. 
with decreased hours, in one factory there had been decreased output exactly in proportion to the less number of hours, whilst in the other factory the output was the same notwithstanding the less number of hours. The conclusion arrived at was that the greatest care must be exercised in basing conclusions on any individual set of results. All circumstances must be taken into account

The Lecturer said his own idea was that the ultimate result depended to a lauge extent upon whether the operatives were over-weighted in the first instance.

Mr. W. HArrison suggested that mental fatigue was of great importance. Workpeople could often be permitted to avoid worry in connection with their work by an attitude of encouragement on the part of those over them.
The Lecturer said that nearly the whole of the fatigue dealt with by his department was mental. Worry was a terrible producer of fatigue and of the condition under which efficiency was lost. Unsuitable food often led to a state of woryy. It was quite true that the sense of worry could often be relieved by encouragement.

On the motion of Mr. Iinrrison, seconded by Mr. Lester, and supported by Mr. T. Fletcher Rolinson, the Lecturer was heartily thanked. Mr. Lester ex. pressed the hope that more meetings on the subject would be held, and Mr. Robinson struck ati optimistic note as to the future of industry - at a time when the opportunities are great and so much is being done by many movements to assist both employers and $t m$ ployed.

\section{GENERAL PROCEEDINGS, AND REPORTS}

\section{LESSONS FROM WOOL CONTROL}

The Huddersfield Text:le Society had a disippoint. ment on the opening night of the session on October 13, for Sir Arthur Goldfinch, Director of Raw Materials, was out of the country and unable to be present. $\mathrm{He}$ had chosen for the title of his lecture "Some Observations on the State Control of Trade and Industry," and the Society were fortunate in securing Mr. E. F. Hitchcock, who gave an address with the same title. Much interest attached to the lecture by reason of $\mathrm{Mr}$. Hitcheock's prominent part in the control of the wool industry during the war, and he admitted that his views were largely based on that experience. $\mathrm{He}$ discountenanced dogmatism, however, and his lecture was a balanced survey of the problem.

Mr. Hitchcock said State control was often regarded very largely from the point of view of theory, but he must confess that he himself had not yet evolved any theory of the function of the State in this matter. because so much depended upon the character of the State itself and the conditions under which it existed. Therefore, he tackled the question from the point of view of a somewhat limited but useful experience of State control, and what he thought were likely to be its practical results under given conditions. Rightly or wrongly, the main population of Europe was thinking on communist lines, and there was a demand on the part of the vast mass of people for a change of status in a communist direction. Granted that what people wanted was bound to come about some time or another, what were the conditions that they had to fulfil? There were, to him, two main conditions-(1) that they must be very careful that any change did not impair the efficiency of industrial management, and (2) that it did not result in a decreased output.

So far as wool control was concerned, it did not start a moment too soon, and it did not go a foot too far. His own view was that it did not go far enough, and that there were enormous inequalities. Some people went off scot free and got more owing to the fnct that other people were restricted. It was quite clear that as a result of control we obtained supplies at a lower price than wuuld otherwise have obtained, and, when all the facts were un the table, he thought the achievement would be regarded as no meat one. But he did not think there was much in common with conditions during the war and the conditions that would prevail during the next few years.

He would like to quote from the report of the German Coal Commission appointed by the Socialist Government in March last to consider the nationalisation of the coal industry. They said: "It is a natural and obvious idea that the whole of the coal. mining industry and of the sale of coal products should be owned by the State. The Commission. however, is unanimously of opinion that the existing methods of organising those mines which are actually State-owned do not satisfy economic conditions. These methods must be reformed throughout before nationalisation can be extended. The entire organisation of a normal State-owned mine is, un account of its bureaucratic principles, an immense obstacle in the way of the economic exploitation of the mines." The report declared against nationalisa. tion unless there could be a divorce between the industrial and the other functions of the State. In the State-owned mines, there was control upon control and a complication of methods and organisation, instead of confidence and incentive to independent work. Experience showed him that what was stated in that report was essentially true of our own Civil Service. Giving them all credit for their honesty, sincerity, and public spirit, nothing more could be expected of young men who left the universities at 23 or 24 years of age and found in the Service a state of affairs which was enough to sap the initiative and adventure in any young man. On the other hand, the supporters of nationalisation were quite right to point to the wretched condition of private industry, the economies of unified control, and the status of the worker. Private industry had not got an argument to stand on until it took action along those lines that would associate the worker, so far as he was competent to associate, with the business itself and the results of the business. 